\title{
A Preliminary Analysis on the Night Cooling Potential of Photovoltaic/thermal (PV/T) Panels for European Cities
}

\author{
Dragos-Ioan Bogatu*, Ongun Berk Kazanci, and Bjarne W. Olesen \\ International Centre for Indoor Environment and Energy, Department of Civil Engineering, Technical University of Denmark
}

\begin{abstract}
A model of three PV/T collectors of $3.9 \mathrm{~m}^{2}$ area was developed in TRNSYS for analysing its cooling potential in Athens, Greece; Madrid, Spain; Milan, Italy; Bucharest, Romania; Frankfurt, Germany; Copenhagen, Denmark and Oslo, Norway between $1^{\text {st }}$ of May and $30^{\text {th }}$ of September. An in-depth analysis over the model was conducted for Copenhagen, Denmark where supply temperature, collector slope, and flow rate were varied. For the other six European cities subject to different climates, the only parameter varied was the supply temperature while the optimum slope for electricity production was selected for the PV/Ts. A coverage ratio was determined, representing the amount of cooling demand of an office room covered by the cooling energy produced by the PV/Ts. With respect to Europe, a higher cooling potential was found for northern climates. For a representative supply temperature of $21^{\circ} \mathrm{C}$, a specific cooling power ranging from 35 to $70 \mathrm{~W} / \mathrm{m}^{2}$ was determined. Finally, the same trend was visible for the coverage ratio, ranging from $55 \%$ to $120 \%$. The results show that this cooling technology has a potential to be further used, when coupled to appropriate room cooling systems, such as water-based high temperature cooling systems.
\end{abstract}

\section{Nomenclature}

$c$

$h_{c}$

U

$u$

$T_{\text {surf,PV/T }}$

$T_{a}$

$R_{\text {bottom }}$

$\lambda_{\text {ins }}$

$L_{\text {ins }}$

Re

SHGC

$T_{\text {supply }}$

$P_{\text {cool,spec }}$

$E_{\text {cool,spec }}$

$E_{\text {cool,prod }}$

$E_{\text {use }}$

\section{Specific heat}

Convective heat transfer coefficient

Heat transfer coefficient

Wind speed

$\mathrm{PV} / \mathrm{T}$ mean surface temperature

Ambient temperature

Thermal resistance

Thermal conductivity

Thermal insulation thickness

Reynolds number

Solar heat gain coefficient

Supply temperature

Specific cooling power

Specific cooling energy

Total cooling energy

Total energy use
$\mathrm{kJ} / \mathrm{kg} \cdot \mathrm{K}$

$\mathrm{W} / \mathrm{m}^{2} \cdot \mathrm{K}$

$\mathrm{W} / \mathrm{m}^{2} . \mathrm{K}$

$\mathrm{m} / \mathrm{s}$

${ }^{\circ} \mathrm{C}$

${ }^{\circ} \mathrm{C}$

$\mathrm{m}^{2} . \mathrm{K} / \mathrm{W}$

$\mathrm{W} / \mathrm{m} . \mathrm{K}$

$\mathrm{W} / \mathrm{m}^{2} . \mathrm{K}$

\section{Introduction}

During the night, the sky can reach temperatures below $0^{\circ} \mathrm{C}$ [1]. Thus, water circulated through a photovoltaic/thermal panel can be cooled by releasing heat through the radiative heat exchange between the sky and the panel's surface [2].

Since the radiative heat exchange is the main driver, it has the highest influence over the cooling output of the $\mathrm{PV} / \mathrm{Ts}$. As literature suggests, the main actor is the sky temperature followed by air temperature, relative humidity, wind speed and cloud coverage [3-6]. Nevertheless, these parameters can also influence the cooling output through convection, which can increase it if the air temperature is lower than the surface temperature of the PV/T or decrease it otherwise [3-7].
Although its dependency on the climate makes this technology similar to other renewable energy production methods, it was chosen as the utilization factor of PV/Ts can be increased. In addition, it can aid the transition towards the 2030 climate \& energy framework by contributing to higher renewable energy share, higher energy efficiency and lower greenhouse gas emissions [8]. Thus, this study aims at making a preliminary analysis on the cooling potential of photovoltaic/thermal panels for European cities with the use of the TRNSYS17 software.

\section{Methodology}

The following section presents the main models and assumptions made for each simulation in TRNSYS. The cooling potential was first investigated for Copenhagen, Denmark with the model being afterwards extended to the rest of the cities. All simulations were run using a 1 minute time-step.

\subsection{PV/T model}

The PV/T simulation model developed in TRNSYS17 is presented in Figure 1. Component Type560 was used to model three PV/T collectors with a total area of $3.9 \mathrm{~m}^{2}$.

The necessary parameters were obtained from a previously validated model described by Pean et al. [3]. Table 1 shows all the PV/T parameters used in this study.

The parameters were analyzed and corroborated with the data sheet provided by the manufacturer and thus some of them, marked with $(*)$, were recalculated and replaced [9]. First, the tube diameter was found to be $0.018 \mathrm{~m}$. Secondly, in this study a mixture of $40 \% / 60 \%$ propylene-glycol/water was chosen to prevent carrier freezing in the system. Thus, the fluid specific heat

Corresponding author: drabo@byg.dtu.dk 
selected was $3.856 \mathrm{~kJ} / \mathrm{kg} . \mathrm{K}$, while the heat transfer coefficient between the fluid and the tube wall resulted in a value of $96.9 \mathrm{~W} / \mathrm{m}^{2} \mathrm{~K}$ because of the changes made to the tube diameter and heat carrier.

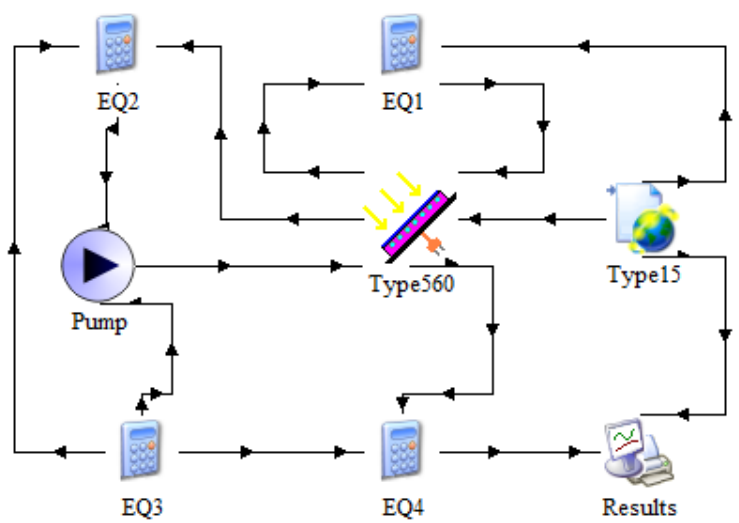

Fig. 1. TRNSYS PV/T simulation model.

Table 1. PV/T properties.

\begin{tabular}{|l|l|l|}
\hline Parameter & Unit & Value \\
\hline Collector length & $\mathrm{m}$ & 1.315 \\
\hline Collector width & $\mathrm{m}$ & 0.996 \\
\hline Absorber plate thickness & $\mathrm{m}$ & 0.001 \\
\hline $\begin{array}{l}\text { Thermal conductivity of the } \\
\text { absorber }\end{array}$ & $\mathrm{W} / \mathrm{m} . \mathrm{K}$ & 380 \\
\hline Number of tubes & - & 15 \\
\hline Tube diameter* & $\mathrm{m}$ & 0.018 \\
\hline Bond width & $\mathrm{m}$ & 0.01 \\
\hline Bond thickness & $\mathrm{m}$ & 0.001 \\
\hline Bond thermal conductivity & $\mathrm{W} / \mathrm{m} . \mathrm{K}$ & 380 \\
\hline Resistance of substrate material & $\mathrm{m}{ }^{2} . \mathrm{K} / \mathrm{W}$ & 0.001 \\
\hline Resistance of back material & $\mathrm{m}{ }^{2} . \mathrm{K} / \mathrm{W}$ & 1.56 \\
\hline Fluid specific heat* & $\mathrm{kJ} / \mathrm{kg} . \mathrm{K}$ & 3.856 \\
\hline Reflectance & - & 0.15 \\
\hline Emissivity & - & 0.98 \\
\hline Collector slope & ${ }^{\circ}$ & 45 \\
\hline Fluid heat transfer coefficient* & $\mathrm{W} / \mathrm{m}^{2} . \mathrm{K}$ & 96.9 \\
\hline PV cell reference temperature & ${ }^{\circ} \mathrm{C}$ & 25 \\
\hline PV cell reference radiation & $\mathrm{W} / \mathrm{m}^{2}$ & 1000 \\
\hline $\begin{array}{l}\text { PV efficiency at reference } \\
\text { condition }\end{array}$ & $\% \%$ & 18.43 \\
\hline
\end{tabular}

Weather data required as input for the $\mathrm{PV} / \mathrm{T}$ collector was supplied through the Type15 component from ASHRAE IWEC files [10]. An equation component (EQ1) provided the values for the top heat transfer coefficient, $h_{\mathrm{c} \text {,mix }}$, as a function of the forced and free convection along with the back heat transfer coefficient

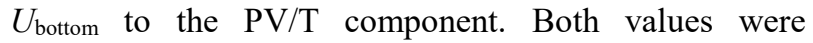
calculated according to the formulae found in Duffie and Beckman [11]:

$$
\begin{gathered}
h_{\mathrm{c}, \text { mix }}=\left(h_{\mathrm{c}, \text { forced }}{ }^{3}+h_{\mathrm{c}, \text { free }}\right)^{1 / 3} \\
h_{\mathrm{c}, \text { forced }}=2.8+3 \cdot u \\
h_{\mathrm{c}, \text { free }}=1.78 \cdot\left(T_{\text {surf,PV} / \mathrm{T}}-T_{\mathrm{a}}\right)^{1 / 3} \\
U_{\text {bottom }}=1 / R_{\text {bottom }}=\lambda_{\text {ins }} / L_{\text {ins }}
\end{gathered}
$$

The wind speed, the mean surface temperature of the $\mathrm{PV} / \mathrm{T}$, and the ambient temperature were taken from the $\mathrm{PV} / \mathrm{T}$ and the weather component. The back heat transfer coefficient was approximated only to the conductive thermal resistance of the insulation due to the lower magnitude of the radiative and convective resistances to the environment [11]. Thus, the back heat transfer coefficient was equal to $0.64 \mathrm{~W} / \mathrm{m}^{2} . \mathrm{K}$, as a $0.07 \mathrm{~m}$ thick thermal insulation with a thermal conductivity of 0.045 $\mathrm{W} / \mathrm{m} . \mathrm{K}$ was used.

The second equation component, EQ2, was created in order to control the pump as a function of the temperature difference between the supply and return of the PV/T component while EQ4 and Results were components only used for data handling. Finally, a third equation component, EQ3, was used for the parameter variation process. Thus, results could be obtained for multiple supply temperatures, flow rates, collector slopes and locations by running the simulation process only once.

\subsection{Parametric analysis for Copenhagen, Denmark}

With the simulation model described above, a more thorough analysis was made for Copenhagen, Denmark. For the simulation, three $\mathrm{PV} / \mathrm{T}$ modules connected in series were considered, resulting in a total area of $3.9 \mathrm{~m}^{2}$.

A water supply temperature variation between $7^{\circ} \mathrm{C}$ and $25^{\circ} \mathrm{C}$ was found suitable to determine the behaviour of $\mathrm{PV} / \mathrm{Ts}$. This temperature range covers temperatures found in air-conditioning systems and in water-based high temperature cooling systems [12]. As cooling water with $\mathrm{PV} / \mathrm{Ts}$ during night is a high temperature cooling application, a $3 \mathrm{~K}$ step variation was chosen from $7^{\circ} \mathrm{C}$ to $16^{\circ} \mathrm{C}$, while a $1^{\circ}$ step size until $25^{\circ} \mathrm{C}$.

For the flow rate, two values were investigated. 121 $\mathrm{kg} / \mathrm{h}$ was the optimum flow determined and used in the simulations of Pean et al. [3]. The second value, 11000 $\mathrm{kg} / \mathrm{h}$, was found representative for achieving a turbulent flow $(\operatorname{Re}>3000)$. This high value was necessary because of the high number of pipes per PV/T module and their small diameter. Even though the panels cannot withstand such a high flow rate according to the PV/T data sheet [9], this case was still investigated as a turbulent flow regime would be advantageous for operation.

Finally, the cooling potential was determined for three south oriented collector slopes, $0^{\circ}, 45^{\circ}$ and $90^{\circ}$. These values represent horizontal, electricity production optimum and vertical mounting, and were deemed sufficient in order to obtain a broad view of the PV/T cooling potential. Moreover, horizontal and vertical positioning were selected as it would make it more likely for architects to include PV/T panels in their designs (e.g. covering horizontal surfaces on roofs or covering façades in buildings).

\subsection{PV/T cooling potential for multiple European cities}

The rest of the simulations for the rest of the European cities were made for one flow rate, $121 \mathrm{~kg} / \mathrm{h}$ and a single 
collector slope (i.e. the optimum slope for electricity production). The cities along with their corresponding collector slopes are presented in Table 2.

Table 2. Cities investigated and corresponding collector slopes $[13,14]$.

\begin{tabular}{|c|c|c|c|}
\hline City & Country & Acronym & $\begin{array}{c}\text { Collector } \\
\text { slope }{ }^{\circ} \text { ] }\end{array}$ \\
\hline Athens & Greece & ATH & 32 \\
\hline Madrid & Spain & MAD & 37 \\
\hline Milan & Italy & MIL & 37 \\
\hline Bucharest & Romania & BUC & 35 \\
\hline Frankfurt & Germany & FRA & 38 \\
\hline Oslo & Norway & OSL & 44 \\
\hline
\end{tabular}

The collector slopes for the European cities mentioned were collected from PVGIS software by optimizing the collector slope with respect to annual electricity production [13]. The slopes found were further corroborated with the PVSYST software by following the same process [14].

The ASHRAE IWEC weather data for each city was used as input for the simulations [10]. The cooling period, $1^{\text {st }}$ of May $-30^{\text {th }}$ of September was used for all the simulations.

\subsection{Office room model}

An office room model was created in the same simulation software. The model was based on an experimental chamber, Chamber 6 , located in the laboratory of the International Centre for Indoor Environment and Energy (ICIEE) at the Technical University of Denmark.

The chamber had a total area of $22.7 \mathrm{~m}^{2}(4.2 \times 5.4 \mathrm{~m}$ $\mathrm{W} \times \mathrm{L}$ ) and a height of $2.7 \mathrm{~m}$ designed as a two-person office (Figure 2). Since the chamber was located in the laboratory, all walls are internal. Moreover, both the walls and windows were insulated from the surroundings.

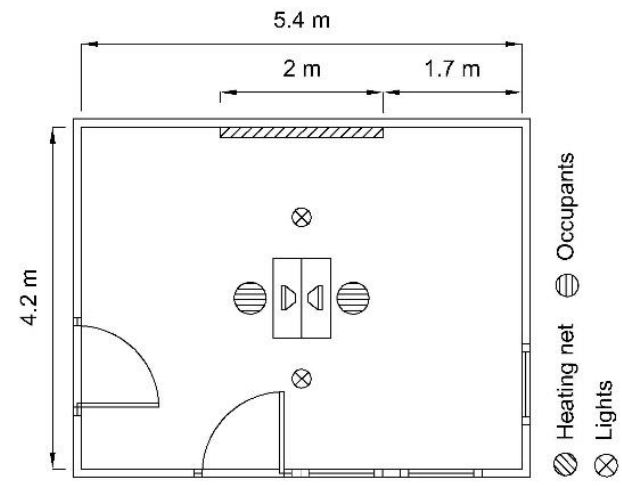

Fig. 2. Office room representation.

The internal heat loads (Table 3 ) present in the room were set on a schedule representing working hours from 08:00 to 18:00 where the gains were operating at full capacity. Additionally, as the chamber had no external wall, in reality a $1.5 \mathrm{~m}^{2}$ heating net was employed on the south side to simulate the solar heat gains present during the day.
Table 3. Internal heat gains.

\begin{tabular}{|c|c|c|c|}
\hline Gains & Units & $\begin{array}{c}\text { Heat Gain } \\
\text { Per Unit }\end{array}$ & $\begin{array}{c}\text { Total Heat } \\
\text { Gain }\end{array}$ \\
\hline- & - & {$[\mathrm{W}]$} & {$[\mathrm{W}]$} \\
\hline Occupant & 2 & 90 & 180 \\
\hline Computer & 2 & 150 & 300 \\
\hline Light & 2 & 10 & 20 \\
\hline Total & 6 & - & 500 \\
\hline
\end{tabular}

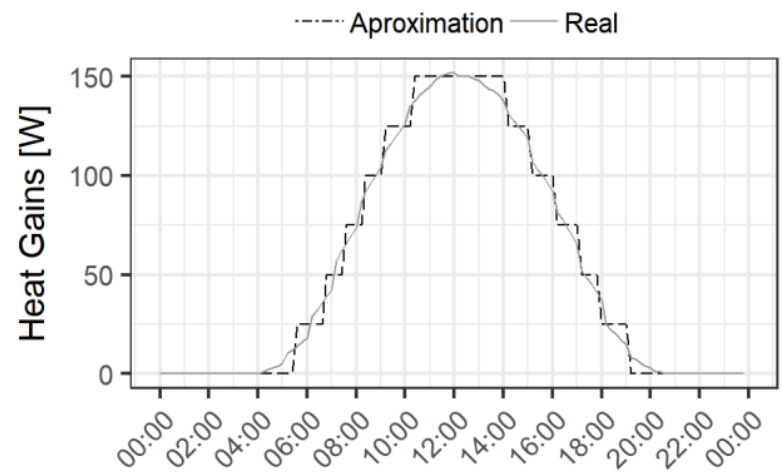

Fig. 3. Solar heat gains processing.

In the software, a time dependent forcing function was used to simulate the solar heat gains as internal heat gains. The solar heat gains profile (Figure 3) was determined by making an average of the solar heat gains on a south facing wall for the 153 days representing the Danish cooling period ( $1^{\text {st }}$ of May $-30^{\text {th }}$ of September $)$.

The internal values were then found by assuming a double glazing window with a $U$-value of $0.53 \mathrm{~W} / \mathrm{m}^{2} . \mathrm{K}$ and a $S H G C$ of 0.283 . Finally, in order create the same profile as for the heating net present in the chamber, the profile found was rounded to steps of $25 \mathrm{~W}$, similar to the ones of the controller employed in the chamber.

\subsection{Coverage ratio}

In order to determine the necessary cooling energy to cover the room's cooling demand, an ideal cooler was used for removing the extra heat such that an air temperature of maximum $26^{\circ} \mathrm{C}$ was maintained in the climatic chamber. Moreover, no ventilation strategy was used for the simulation and no differentiation was made between weekend and weekdays, thus the heat gains were operating every day during working hours.

The total energy use of the ideal cooler determined for the cooling season ( $1^{\text {st }}$ of May $-30^{\text {th }}$ of September) was then compared with the PV/T's cooling energy production for the same period. By determining the share of the cooling energy use covered by the PV/Ts, a coverage ratio was defined and calculated for each city analyzed.

\section{Results}

\subsection{Reference model comparison}

After making the necessary changes in the parameters of the model to better reflect the product and to prevent pipe 
freezing during winter operation, a comparison was made to the reference model of Pean et al. [3]. The comparison between the two models with respect to cooling power and energy can be seen in Figures 4 and 5.

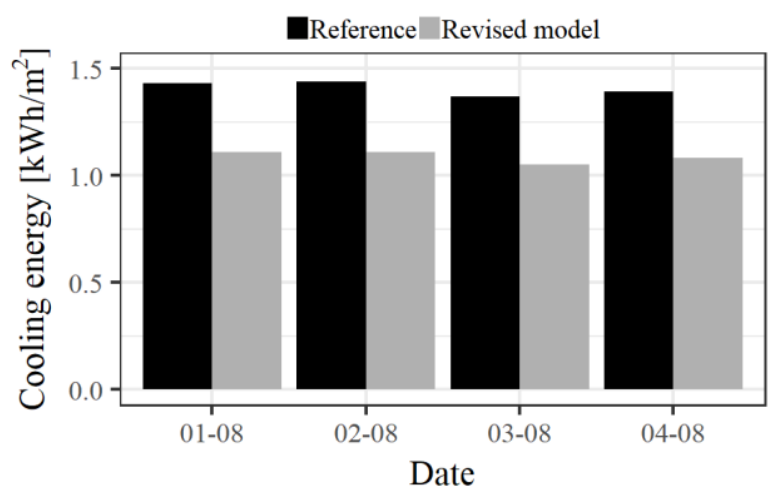

Fig. 4. Cooling energy- reference vs. revised model.

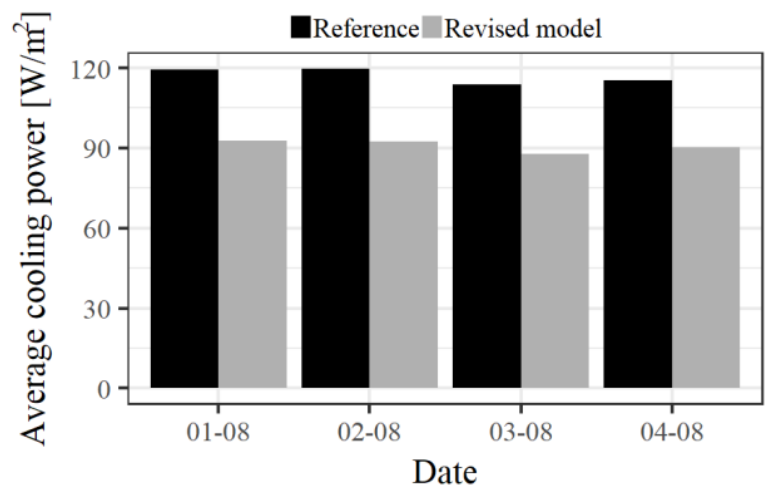

Fig. 5. Average cooling power - reference vs. revised model.

The simulations were made between the nights of $1^{\text {st }}$ and $4^{\text {th }}$ of August 1999 for Copenhagen, Denmark. Moreover, both models utilize the IWEC weather file for the same location as input.

The results show that both the average cooling power and cooling energy decreased by approximately
$23 \%$ in the revised model. The $\mathrm{PV} / \mathrm{Ts}$ produced an average specific cooling power between 88 and $91 \mathrm{~W} / \mathrm{m}^{2}$ and an average specific cooling energy of $1.1 \mathrm{kWh} / \mathrm{m}^{2}$ after the addition of glycol in the mixture and the change in pipe diameter for the days analysed. Nevertheless, although smaller, the specific cooling power values found are in the range available in literature $[2,15]$.

\subsection{Parametric analysis Copenhagen}

In this study, focus was set on cold water production. Electricity production was also investigated however, in order to have a better overview of the results.

As water circulation would normally be present during the day when electricity is produced, a simplification was made. No control was defined, allowing water to be circulated continuously throughout the simulation. Therefore, no optimization was made with respect to the pump's energy use. The results represent the theoretical maximum for both cold water and electricity production as every instance where the values were greater than zero were taken into account for the analysis.

The average specific cooling power observed for the two flow rates, laminar $(121 \mathrm{~kg} / \mathrm{h})$ and turbulent $(11000$ $\mathrm{kg} / \mathrm{h}$ ) with respect to collector slope and supply temperature for Copenhagen, Denmark is presented in Figure 6.

For both flows and for every collector slope investigated, the average specific cooling power is increasing for an increase in supply temperature. Moreover, slight changes in slopes can be seen in two points, $10^{\circ} \mathrm{C}$ and $13^{\circ} \mathrm{C}$, the curve becoming steeper as the supply temperature increases. With respect to collector slope, $P_{\text {cool,spec }}$ is highest for a $90^{\circ}$ slope, lower for a $45^{\circ}$ one, and lowest for a horizontal positioning of the $\mathrm{PV} / \mathrm{Ts}$.

For a laminar flow, $P_{\text {cool,spec }}$ increases from $14 \mathrm{~W} / \mathrm{m}^{2}$ for a $7^{\circ} \mathrm{C}$ supply temperature to $87 \mathrm{~W} / \mathrm{m}^{2}$ for $25^{\circ} \mathrm{C}$ for a $45^{\circ}$ collector slope respectively. From a $45^{\circ}$ to a $90^{\circ}$ slope,

$$
\begin{aligned}
& \square 121 \mathrm{~kg} / \mathrm{h}, 0^{\circ} \rightarrow 121 \mathrm{~kg} / \mathrm{h}, 45^{\circ} \triangle 121 \mathrm{~kg} / \mathrm{h}, 90^{\circ} \\
& -11000 \mathrm{~kg} / \mathrm{h}, 0^{\circ}-11000 \mathrm{~kg} / \mathrm{h}, 45^{\circ}-11000 \mathrm{~kg} / \mathrm{h}, 90^{\circ}
\end{aligned}
$$

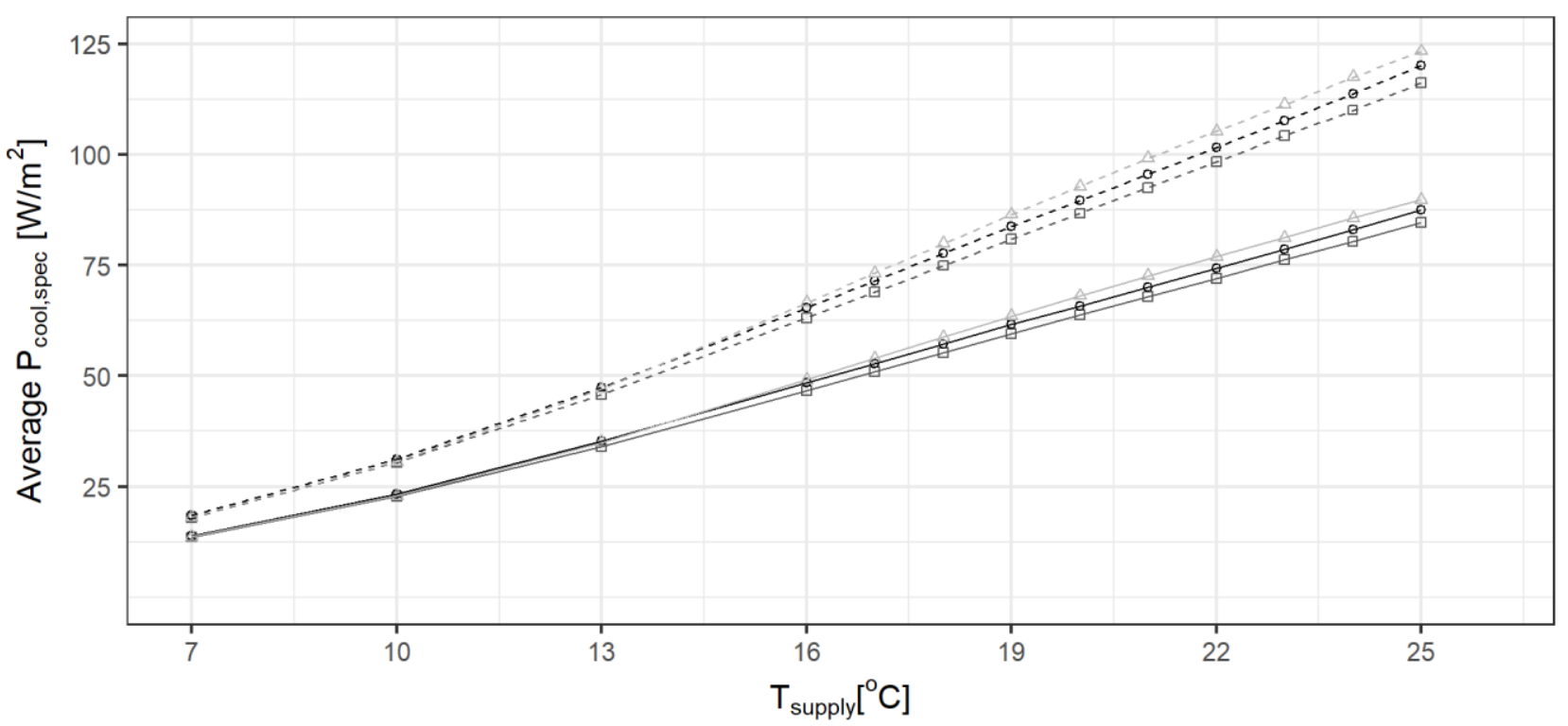

Fig. 6. Parametric analysis for Copenhagen, Denmark, $1^{\text {st }}$ of May $-30^{\text {th }}$ of September. 


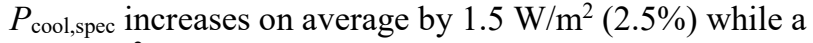
$1.9 \mathrm{~W} / \mathrm{m}^{2}(3.2 \%)$ decrease is registered for a $0^{\circ}$ slope. In addition, achieving a turbulent flow would result on a $36 \%$ average increase of $P_{\text {cool,spec. }}$.

Figure 7 gives a more complete overview over the entire cooling season for the reference flow, $121 \mathrm{~kg} / \mathrm{h}$. In it, the total cooling energy and electricity can be observed for the mentioned period. Values are given for the three analysed collector slopes and the same supply temperature range.

As expected, the electricity production is highest for a $45^{\circ}$ collector slope, which is closest to the optimum collector slope for electricity production $\left(41^{\circ}\right.$, according to PVGIS and PVSYST software $[13,14]$ ). The minimum output however is registered for a vertical positioning of the $\mathrm{PV} / \mathrm{T}$.

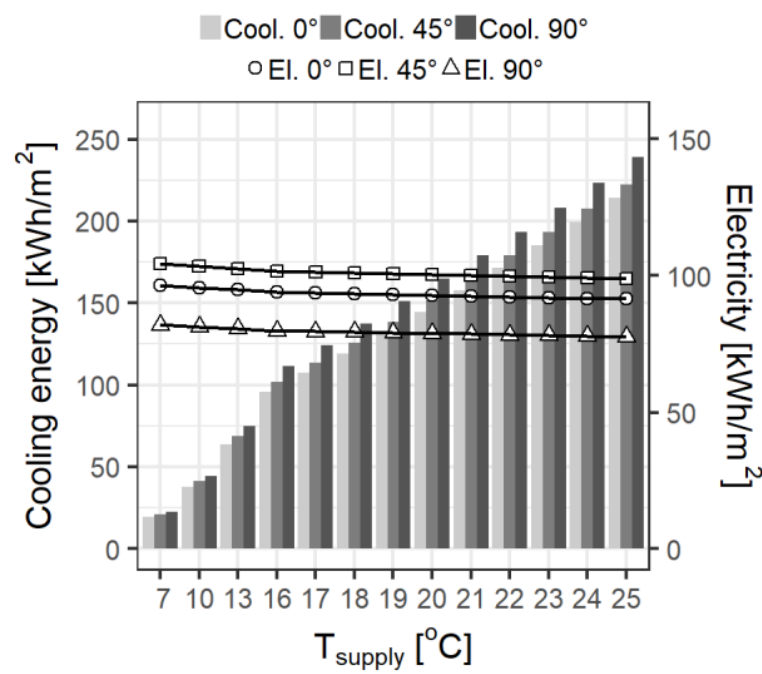

Fig. 7. Electricity and cooling energy per square meter of PV/T, $1^{\text {st }}$ of May $-30^{\text {th }}$ of September, Copenhagen, Denmark.

With respect to the cooling energy, the $\mathrm{PV} / \mathrm{T}$ s register the highest production for a vertical orientation while the least for a horizontal one. In addition, the same linear increase for a supply temperature between $16^{\circ} \mathrm{C}$ and $25^{\circ} \mathrm{C}$ can be noticed as in the case of $P_{\text {cool,spec. }}$.

A $7 \%$ decrease in cooling energy is observed on average between a $90^{\circ}$ and a $45^{\circ}$ slope while a horizontal positioning reduces it by $13 \%$. On the other hand, the

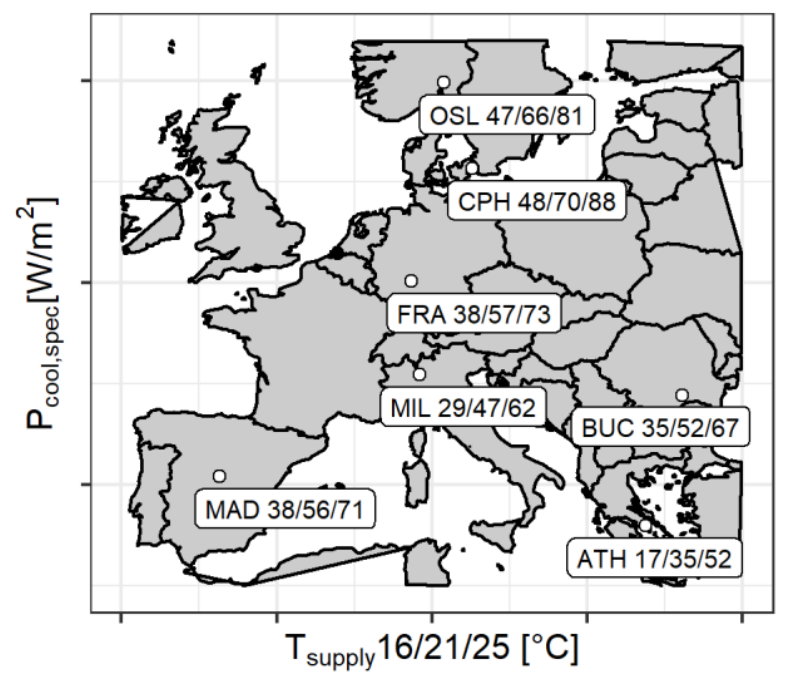

electricity production decreases by $21 \%$ for a $90^{\circ}$ slope while with only $7 \%$ for a $0^{\circ}$ slope with respect to $45^{\circ}$. This translates in a maximum reduction in cooling energy of $31 \mathrm{kWh} / \mathrm{m}^{2}$ while only a maximum of $20 \mathrm{kWh} / \mathrm{m}^{2}$ in electricity production for a $\mathrm{T}_{\text {supply }}$ of $25^{\circ} \mathrm{C}$.

\subsection{Cooling potential of PV/T panels in European cities and coverage ratio}

Several cities were chosen to provide a broad overview of the cooling potential of PV/Ts in different European climates. Figure 8 shows the specific cooling power and energy for each chosen city as a function of supply temperature for the cooling period analysed, $1^{\text {st }}$ of May $30^{\text {th }}$ of September.

As this technology's potential lies within the scope of high temperature cooling, the supply temperature range investigated was reduced between only $16^{\circ} \mathrm{C}$ and $25^{\circ} \mathrm{C}$. Moreover, the values seen in Figure 7 are only given for three $T_{\text {supply }}, 16,21$ and $25^{\circ} \mathrm{C}$.

Copenhagen, Denmark and Oslo, Norway have the highest potential for cold water production, with specific cooling powers of $88 \mathrm{~W} / \mathrm{m}^{2}$ and $81 \mathrm{~W} / \mathrm{m}^{2}$ for a supply water temperature of $25^{\circ} \mathrm{C}$. The second group with respect to average specific cooling power, Frankfurt, Germany, Madrid, Spain, Bucharest, Romania have a maximum $P_{\text {cool,spec }}$ of around $70 \mathrm{~W} / \mathrm{m}^{2}$ for a $\mathrm{T}_{\text {supply }}$ of $25^{\circ} \mathrm{C}$, while a minimum between 35 and $38 \mathrm{~W} / \mathrm{m}^{2}$ if $\mathrm{T}_{\text {supply }}$ is $21^{\circ} \mathrm{C}$. The lowest cooling potential can be observed for Milan, Italy and Athens, Greece. Here, $P_{\text {cool,spec }}$ reaches values as low as 17 to $38 \mathrm{~W} / \mathrm{m}^{2}$ for a $21^{\circ} \mathrm{C}$ supply temperature. For all the cities mentioned, the specific cooling energy over the entire cooling period shows a similar trend, an increase in the cooling potential of $\mathrm{PV} / \mathrm{Ts}$ from south to northern Europe.

The $P_{\text {cool,spec }}$ values resulted for a supply temperature between 16 and $21^{\circ} \mathrm{C}$ from the study match the values presented in the literature. Eicker et al. show that $P_{\text {cool,spec }}$ should be higher for Stuttgart, Germany $\left(100-120 \mathrm{~W} / \mathrm{m}^{2}\right)$, a city close to Frankfurt from both a geographic and climatic point of view than for Madrid, Spain (60-65 $\mathrm{W} / \mathrm{m}^{2}$ ) [4]. Furthermore, the $P_{\text {cool,spec }}$ found for Copenhagen, Denmark is around $23 \%$ lower than the one

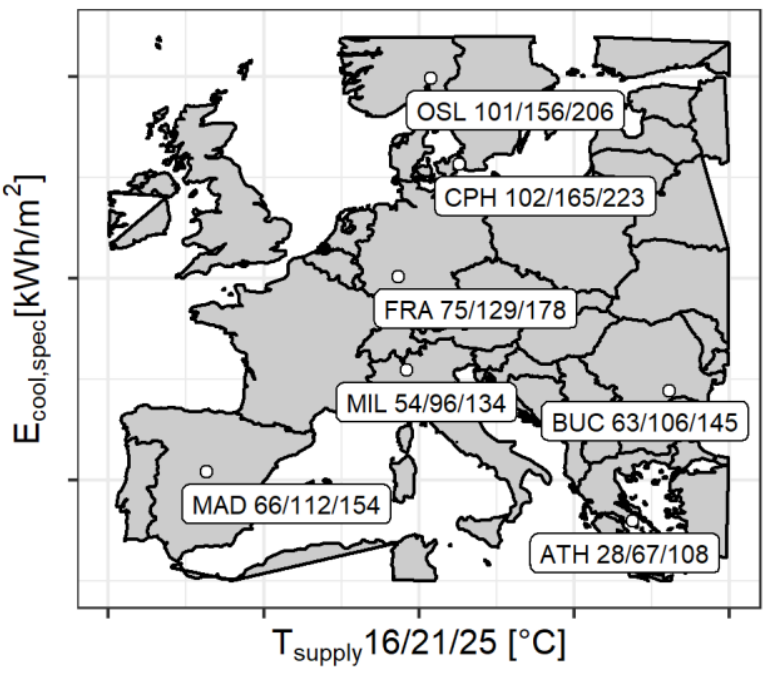

Fig. 8. Specific cooling power and energy for European cities as a function of supply temperature. 
found by Pean et al. [3], difference attributed to the changes brought to the PV/T model. Similar values for $P_{\text {cool,spec }}$ were found as well for Athens, Greece (33.4 $\left.\mathrm{W} / \mathrm{m}^{2}\right)$, Milan, Italy $\left(35.9 \mathrm{~W} / \mathrm{m}^{2}\right)$, Copenhagen, Denmark $\left(42.8 \mathrm{~W} / \mathrm{m}^{2}\right)$ and Oslo, Norway $\left(60 \mathrm{~W} / \mathrm{m}^{2}\right)$ in previous studies [16, 17]. Thus, an assumption was made and $P_{\text {cool,spec }}$ and $E_{\text {cool,spec }}$ found for a $T_{\text {supply }}$ of $21^{\circ} \mathrm{C}$ were considered as representative.

The total cooling energy for the cooling period found as representative, was then compared with the total energy use, required by the ideal cooler to cover the cooling demand of the modelled office. The resulting values are presented in Figure 9 for the European cities analysed. Along with the $E_{\text {use }}$ and $E_{\text {cool,prod, a percentage is given }}$ which represents the coverage ratio previously described.

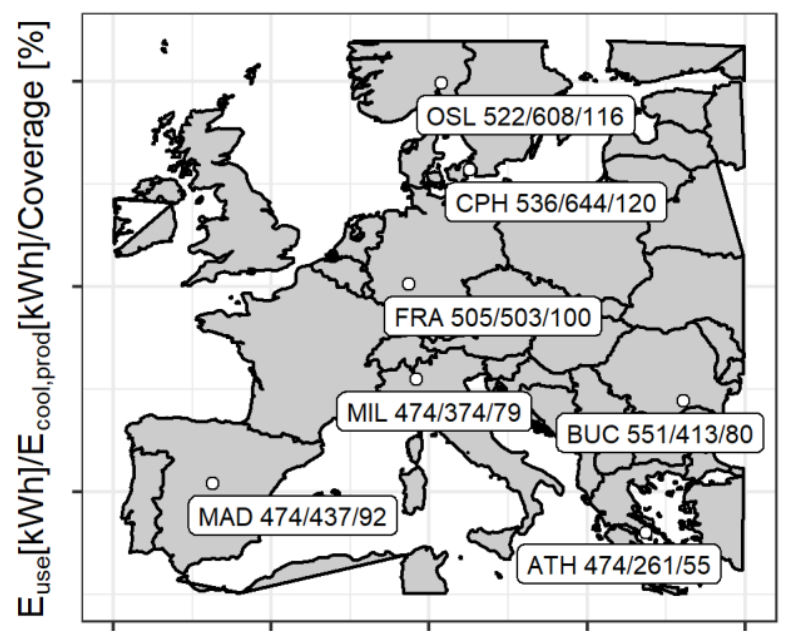

Fig. 9. Energy use, cooling energy produced and coverage ratio for the cities analysed.

For a water supply temperature of $21^{\circ} \mathrm{C}$, the PV/Ts present a high coverage capability for northern Europe. The same could be said for Frankfurt, Germany, but considering the limited data, further investigation is required in its case. Nevertheless, the high coverage ratio in these cases is due to the relative difference between cooling energy between cities, which is bigger than for the energy use. The energy use is fairly constant between close locations as the only modified parameter is the incident solar radiation through the window.

The PV/Ts are most effective for Oslo, Norway and Copenhagen, Denmark where the production exceeds the demand with as much as $20 \%$. Around central Europe, latitude wise, Madrid, Spain; Bucharest, Romania; Milan, Italy; and Frankfurt, Germany present cover ratios between $79 \%$ and $100 \%$. At the other end, only $55 \%$ of the energy use can be covered by the PV/Ts in Athens, Greece.

\section{Discussion}

The revised model of the PV/Ts led to a reduction in cooling power and energy of around $23 \%$ compared to the model of Pean et al. [3]. This difference was a consequence of the fluid mixture, glycol/water $40 / 60 \%$ mixture and the smaller diameter of the pipes. The percentage of propylene glycol in the mixture can differ from one location to another yet for the sake of simplicity it was kept constant for all the simulations made.

This study focused on the cooling potential of PV/Ts, However, PV/Ts are mainly used for electricity and hot water production. Thus, their operation is expected to be year round. The addition of glycol in the fluid mixture allows for a year round operation by preventing fluid freezing in the pipes during winter while also displaying the ability of taking advantage of night time radiative cooling. Consequently, even though the cooling potential of the PV/Ts was affected by the changes made, the results present a more realistic approach.

Pean et al. found in their study that TRNSYS underestimates the cooling potential when comparing to the experiment [3]. Planned experiments will provide further details and opportunities to study the simulation models. Moreover, the validation of the revised model would further allow the investigation of the influence of rain on the cooling potential and the ability of the simulation software to account for it, another question raised earlier by Pean et al. [3].

First, the increase in cooling energy with respect to supply temperature is expected as the temperature difference between the sky temperature and that of the $\mathrm{PV} / \mathrm{T}$ surface increases. The electricity output however decreases with the increase in supply temperature. The latter occurs as water is circulated as well during the day in the simulations. Thus, as the supply temperature increases, the PV/Ts are being cooled less which leads to a lower electricity production [18].

The parametric analysis for Copenhagen, Denmark confirmed that employing $\mathrm{PV} / \mathrm{Ts}$ for cold water production through night radiative cooling represents a possibility for coupling with high temperature cooling applications [19]. As observed, a change in supply temperature of $1 \mathrm{~K}$ has a higher impact on cooling power if the supply temperature is higher than $16^{\circ} \mathrm{C}$ than for a lower value. In addition, a turbulent flow could also increase the cooling power. Nevertheless, this would result in an increased energy use for the pumps in the system. On top of that, as the PV/Ts cannot withstand such a high flow rate, their design would require changes. In this case, the trade-off between the increased pumping power and the additional electricity production should be investigated.

With respect to both average specific cooling power and total cooling energy over the cooling period ( $1^{\text {st }}$ of May $-30^{\text {th }}$ of September), a difference between different collector slopes was observed. This variation occurs due to the collector orientation, south, and solar azimuth. Because of the sun's movement during summer, from a solar azimuth of $+135^{\circ}$ to $-135^{\circ}$, a collector oriented South with a $0^{\circ}$ slope would have solar radiation incident over a longer period, during early morning and late afternoon than for $45^{\circ}$ and $90^{\circ}$ respectively (Figure 10) [11]. During those periods, the surface of the PV/Ts would absorb extra heat at a slope closer to $0^{\circ}$, which would decrease their cooling potential.

Therefore, the total cooling energy increases from a $0^{\circ}$ slope to a vertical one. On the other hand, the electricity production is highest for a $45^{\circ}$ slope, smaller for a horizontal slope while smallest for a vertical one. This 
coincides with data found in literature, where the annual solar radiation collection presents the same relationship with collector slopes for the northern hemisphere [20]. Even though the slope of the PV/Ts can be optimized depending on the application, the electricity production should be prioritized. This is due to the electricity production being more susceptible to collector slope changes than cooling, as it can be reduced by as much as $21 \%$ from the optimum to the vertical slope compared to only $7 \%$ with respect to specific cooling energy from a $90^{\circ}$ slope to a $45^{\circ}$ one.

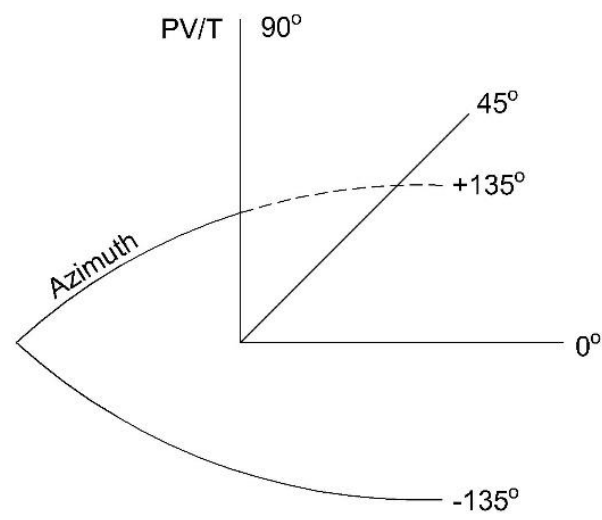

Fig. 10. Explanation of sun's movement with respect to different collector slopes [11,21].

Results from the simulations for the seven cities selected provide a complete picture for the cooling potential over different climates in Europe. As the values were corroborated with the literature and found within the ranges mentioned for each city, they are considered representative for the locations investigated. The general trend observed is an increase in cooling potential from south to north. However, exceptions can be spotted, which can be attributed to the different climates. For instance, Milan, Italy is subject to a humid climate with hot summers while Bucharest, Romania to a humid one with warm summers according to the Köppen climate classification [22]. Also, the same classification shows that both Copenhagen, Denmark and Oslo, Norway present warm summers but the former has oceanic influences as opposed to the continental one of Oslo. Nevertheless, in the latter case, the difference can also be attributed to the collector slope used for Copenhagen, which is not the optimum for electricity production as suggested by the literature. Here, the collector slope selected for Copenhagen is closer to a vertical one which could lead to higher cooling potential than for Oslo.

Another example is the relative humidity that can have an impact as well on the cooling potential according to Pean et al. [3]. The IWEC weather data shows that Madrid, Spain has a lower average relative humidity, $51 \%$, while Bucharest, Romania and Milan, Italy reach $71 \%$ and $72 \%$, respectively, which would explain why the cooling potential of Madrid is higher than for the other two [10].

The difference from the general trend in cooling power and energy values between locations can also be related to the length of the cooling period. For this study, it was assumed that all cities have the same cooling period, $1^{\text {st }}$ of May $-30^{\text {th }}$ of September. In reality, the cooling period can differ from one climate to another. Therefore, it could be probable that simulating the locations with their associated cooling periods would lead to a more uniform increase in cooling potential with respect to latitude.

With respect to the coverage ratio, it is mostly influenced by the cooling energy production from the $\mathrm{PV} / \mathrm{Ts}$ and the cooling demand of the room. The PV/T model is influenced by multiple parameters such as dry bulb temperature, sky temperature, radiation and wind velocity from the weather data which translates into a higher variation in cooling power.

The office room model was kept the same for each location. However, the values for the incident solar heat gains through the window on the south wall varied for each location as a function of the weather file. As the latitude increases, the angle of incidence becomes acute which leads to an increase in solar heat gains. For Bucharest, Romania however, higher peaks were observed in the weather data during midday than for the other locations, which explains the higher cooling demand than for the other locations close with respect to latitude. Moreover, in the IWEC weather data, higher heat gains are present for Copenhagen, Denmark than for Oslo, Norway, which also leads to a higher cooling demand for the former.

It is true that simplifications were made as the ideal cooler does not represent a realistic model of a cooling unit, while the same cooling period was used for the different climates of the cities analyzed. Nevertheless, the coverage ratio values are estimations and are only intended to give a notion of the available cooling potential for PV/Ts for different locations. For an accurate view of this ratio, the ideal cooler present in the chamber should be replaced with a model of a real cooling unit while thorough investigation would be required depending on the cooling system analyzed.

It should also be noted that a reduced cooling demand will allow higher coverage ratios with the same $\mathrm{PV} / \mathrm{T}$ panel areas (or smaller PV/T panel areas for covering given cooling load), which emphasizes the importance of reducing cooling demands in the design phase of buildings.

\section{Conclusion}

This study presents preliminary results for the cooling potential of PV/T panels across multiple European cities. The results prove the potential of night radiative cooling for solar $(\mathrm{PV} / \mathrm{T})$ panels in Europe. Thus, this sustainable cooling technology could lead to significant energy savings by replacing other energy-intensive cooling technologies. Moreover, results show that there is greater potential for night radiative cooling in northern climates than in southern climates.

Both flow rate and collector slope have an influence on the cooling power of PV/Ts. A turbulent flow would increase the cooling power with approximately $36 \%$ while a vertical positioning of the $\mathrm{PV} / \mathrm{Ts}$ would also increase the specific cooling power by $2.5 \%$ on average from $45^{\circ}$, 
which is the optimum slope for electricity production.

The specific cooling power ranges from $35 \mathrm{~W} / \mathrm{m}^{2}$ to $70 \mathrm{~W} / \mathrm{m}^{2}$ from Athens, Greece to Copenhagen, Denmark, respectively, for a supply temperature of $21^{\circ} \mathrm{C}$. The same trend was observed for the coverage ratio, as the $\mathrm{PV} / \mathrm{Ts}$ were able to cover from $55 \%$ to $120 \%$ of the energy use for the office room modelled. Storage tanks could be required due to the fluctuating nature of renewable energy resources while at the same time necessary for the cases where the production is higher than the demand to store the excess cooling energy.

Employing PV/Ts for cooling purposes on top of heat and electricity production would result in a higher utilization factor. Thus, it would increase the benefits from using the technology as well as the PV/Ts' market value. Finally, the results also show that this cooling technology will provide a natural match for high temperature cooling systems due to the temperatures required by such systems and temperatures provided by this cooling technology.

\section{Acknowledgements}

This study was financially supported by EUDP (Det Energiteknologiske Udviklings- og Demonstrationsprogram), project no. 64015-0614 (Solar CHP \& Cooling for Commercial Buildings and Local Distribution), and by the International Centre for Indoor Environment and Energy (ICIEE), Technical University of Denmark (DTU).

\section{References}

1. X. Xu, R. Niu, G. Feng, An Experimental and Analytical Study of a Radiative Cooling System with Flat Plate Collectors, Procedia Eng. 121, 1574-1581 (2015)

2. T. Q. Péan, L. Gennari, B. W. Olesen, O. B. Kazanci, Nighttime radiative cooling potential of unglazed and PV/T solar collectors: parametric and experimental analyses, CLIMAMED 2015, (2015)

3. T. Q. Péan, L. Gennari, O. B. Kazanci, E. Bourdakis, B. W. Olesen, Influence of the environmental parameters on nocturnal radiative cooling capacity of solar collectors, CLIMA 2016, (2016)

4. U. Eicker, M. Dalibard, Photovoltaic-thermal collectors for night radiative cooling of buildings, Solar Energy. 85, 1322-1335 (2011)

5. G. D. Jourbert, R. T. Dobson, Modelling and testing a passive night-sky radiation system, J. Energy South. Afr. 28, 1 (2017)

6. S. Zhang, J. Niu, Cooling performance of nocturnal radiative cooling combined with microencapsulated phase change material (MPCM) slurry storage, Energy Build. 54, 122-130 (2012)

7. E. Hosseinzadeh, H. Taherian, An Experimental and Analytical Study of a Radiative Cooling System with Unglazed Flat Plate Collectors, Int. J. Green Energy 9, 766-779 (2012)
8. European Commission, 2030 climate \& energy framework, https://ec.europa.eu/clima/policies /strategies/2030 en (accessed 30/08/2018)

9. WIOSUN, Combined module PV-Therm polycristalline, $\quad$ http://www.solarzentrumwiosun.com/products/pv-therm/principle-infos (accessed 24/04/2018)

10. ASHRAE, All Regions - Europe WMO Region 6, https://energyplus.net/weather-region/europe_wmo_ region_6 (accessed 21/04/2018)

11. J. A. Duffie, W. A. Beckman, John Wiley \& Sons, Solar Engineering of Thermal Processes, (2013)

12. Y. Jiang, S. P. Corgnati, M. Perino, X. Liu, I. Guide book of new analysis method for HVAC system, IEA EBC 59, I (2016)

13. European Commission, Photovoltaic Geographical Information System, http://re.jrc.ec.europa.eu/pvg tools/en/tools.html (accessed 15/10/2018)

14. A. Mermoud, M. Villoz, PVSYST, http://www.pvsyst.com/en/ (accessed 16/10/2018)

15. E. Bourdakis, B. W. Olesen, F. Grossule, Night time cooling by ventilation or night sky radiation combined with in-room radiant cooling panels including phase change materials, AIWC 2015, (2015)

16. E. Bourdakis, O. B. Kazanci, F. Grossule, B. W. Olesen, Simulation Study of Discharging PCM Ceiling Panels through Night - time Radiative Cooling, ASHRAE Conf. 2016, (2016)

17. O. B. Kazanci, M. Skrupskelis, P. Sevela, G. K. Pavlov, B. W. Olesen, Sustainable heating, cooling and ventilation of a plus-energy house via photovoltaic/thermal panels, Energy Build. 83, 122129 (2014)

18. M.G. Meir, J. B. Rekstad, O. M. Løvvik, A Study of a Polymer-based Radiative Cooling System, Solar Energy 73, 6 (2002)

19. L. Carnieletto, O. B. Kazanci, M. de Carli, B. W. Olesen, Why couple renewable energy sources with radiant systems: Current trends, limitations and potential, Roomvent \&amp, 2018, 965-970 (2018)

20. X. Ji, M. Li, W. Lin, T. Zheng, Y. Wang, Effect of Installation of Solar Collector on Performance of Balcony Split Type Solar Water Heaters, Int. J. photoenergy 2015, (2015)

21. A. L. Johansen, S. Furbo, Solar radiation Educational note on solar radiation, DTU 2016, (2016)

22. M. Kottek, J. Grieser, C. Beck, B. Rudolf, F. Rubel, Meteorol. World Map of the Köppen-Geiger climate classification updated, Z. 15, 259-263 (2006) 